(5) 式によれば, 誤差は $0.68 \%$ であり，筆者らの求めた 新しい(6) 式によれば0.73〜8.82\%となり, たわみ曲線 の式としては, 誤差は多少大きくなるが, 取扱いが簡単 で，実用的にはこれを用いてもよろしいと考えられる。

\section{5.むす び}

本報告は, 1 種類 (外径 $=8 \mathrm{~mm}$, 肉厚 $=1 \mathrm{~mm}$ )のパイ プを用いた結果であり，また，固定部にもやや不備な点 があつて，実験值のバラッキも多少認められたので，挫 届長さ $l_{c r}$ を正確に推定する場合にとつては必らずしも
充分とは考えられないが, 実用には供しうると思われる。 今後は, 固定部の改造によりパイプの外径, 肉厚を変 え, かつ，パイプ内に水を充てんして実際の排水に合つ た条件をつくり，挫届長さ $l_{c r}$ の決定を確かなるのにし たい。また， $n$ と $l_{0}$ の関係も検討する予定である。

\section{参考文献}

1）吉沢, 川島; 昭和 38 年度合同秋季大会研究発表境演要旨集, p. 33 $\sim 35$.

2) Timoshenko \& Gere: Theory of Elastic Stability p. 103.

3) Timoshenko \& Gere: Theory of Elastic Stability p. 105

\title{
1205 水噴流による破砕機構について
}

\begin{tabular}{|c|c|c|c|c|}
\hline 東北大学工学部教授 - 工博 & 吉 & 沢 & 幸 & 雄(正会員) \\
\hline 東北大学工学部助教授・工博 & 川 & 島 & 俊 & 夫(正会員) \\
\hline 東北大学大学院工学研究科博士課程 & ○柳 井 & 田 & 勝 & 哉(正会員) \\
\hline
\end{tabular}

\section{1. は じ め}

水力採炭に関する基礎的な問題である噴流による破砕 機構の解明はいまだなされていない。従来の研究では, 流体を剛体と考え, 弾性論的な方法で水力破砕の問題を 取り扱つている1,2)。本報告は，最近 Bowdenら ${ }^{3)}$ が超 高圧水噴流で行なつた破砕現象と，筆者らの行なつた高 王水噴流による破砕現象とに相似性があることから，こ れらの水力破砕現象を流体力学的に解析する方法を述へ たものであり，水力破砕機構に打けるキャビテーション 現象の問題, めるいは水滴による壞食の問題の解明の一 つとしても有意義と考え，この問題を取り上げたもので める。

\section{2. 実 験方 法}

装置は，資源技術試験所採鉱保安部水力実験室のもの を借用した。ノズル口径 $D_{0}=0.002 \mathrm{~m}$ ，ノズル出口圧力 $P_{0}=540 \mathrm{~kg} / \mathrm{cm}^{2}$, ノズルからの距離 $l=0.17 \mathrm{~m}$, 吹き付忷 角度は $d_{0}=90^{\circ}$ および $90^{\circ}$ 以下の任意の角度であり，吹 き付け時間 $t=1 \mathrm{~min}$ の条件のもとで，アルミ板および ナタアクリル樹脂を破砕し,それらの破砕面を観察した。
ことがわかつた。筆者らは，これらの現象を流体力学的 に考察するために, W. Schach のポテンシャル流れ理 論5)を用いて，破砕面に打ける圧力分有および流速分布 を求めて，それらの相関関係を検討してみた。以下第 1 図により，説明する。

\section{$3 \cdot 1$ 噴流の吹き付け角度と岐点との関係}

噴流の圧力分布および流速分布を破砕面に打いて求め るためには, 噴流の中心軸と岐点との関係を求める必要 がある。したがつて, 破砕面に扣いて流速が 0 ,すなわ ち圧力が最大となる岐点は吹き付け角度を用いると, 上 記の W. Schach の理論より次式で与えられ, かつ第 2 図にこの関係が示される。

$$
\begin{aligned}
e_{1} & =\frac{D_{l}}{\pi}\left[\cos \alpha_{0} \ln \sin \alpha_{0}+\ln \operatorname{ctg} \alpha_{0}+0.693 \cos \alpha_{0}\right. \\
& \left.+\frac{\pi}{2}\left(\operatorname{ctg} \alpha_{0}+\sin \alpha_{0}\right)-\alpha_{0} \sin \alpha_{0}\right] \cdots \cdots \cdots(1)
\end{aligned}
$$

\section{$3 \cdot 2$ 破砕面における噴流作用点}

破砕面に打ける噴流の作用点は, 速度比 $r$ を用いると 次式で表わされる。

$$
x=\frac{D_{l}}{\pi}\left[\cos \alpha_{0} \ln \frac{r^{2}+1-2 r \cos \alpha_{0}}{1-r_{2}}\right.
$$

\section{3. 実験結果之理論的考察}

供試体のアルミ板の破砕面では， 衝撃領域周辺に環状のくぼみが見ら れた。第 1 図に水力破砕機構の概念 図を示した。噴流の衝撃中心部，す

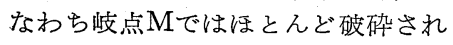
ていない。一方ナタアクリル樹脂で はアルミ板ほど顕著ではないが，や はり衝撃領域周辺部が貝殼状に䟝離 されていることが見うけられた。 A. А. Семерчанら ${ }^{4)}$ によれば, $45^{\circ}$ の吹き付壮による水力破砕が効果的 であることを報告していることから アルミ板に $90^{\circ}$ 以下の任意の角度で 吹き付けて，その破砕の結果を見た が,やはり中心部は破砕されないで, 一方のみの周辺部が破砕されている

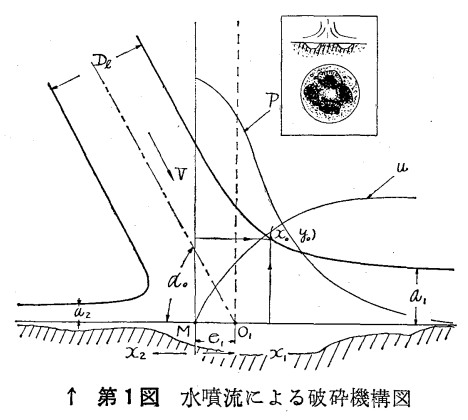

第 2 図噴流の吹き付け角度々 肢点との関係

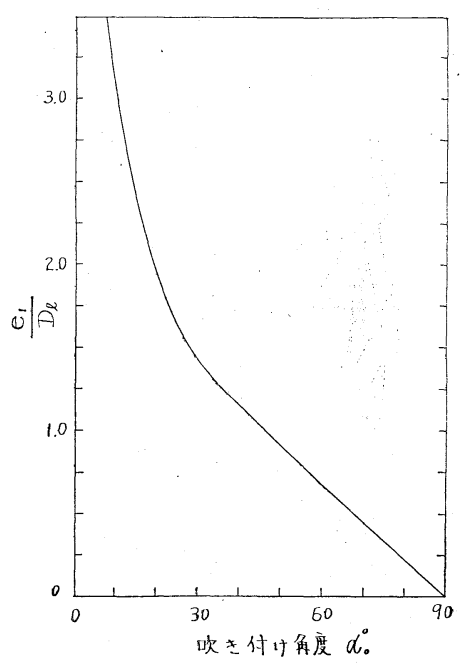



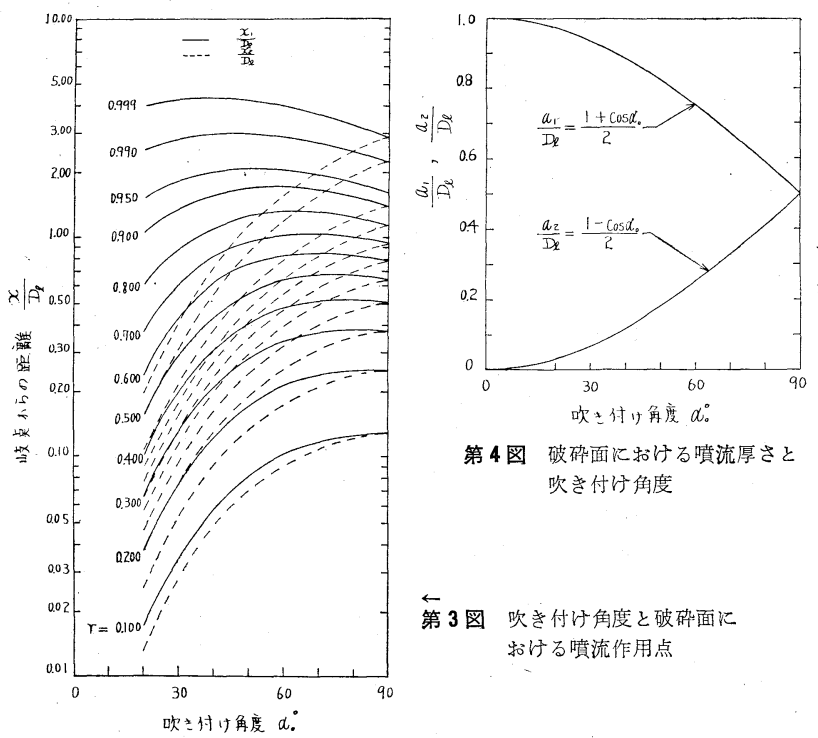

第 4 図破砕面に持ける噴流厚さと 吹き付解度

第 3 図吹き付け角度と破碀面比 抢汀る噴流作用点

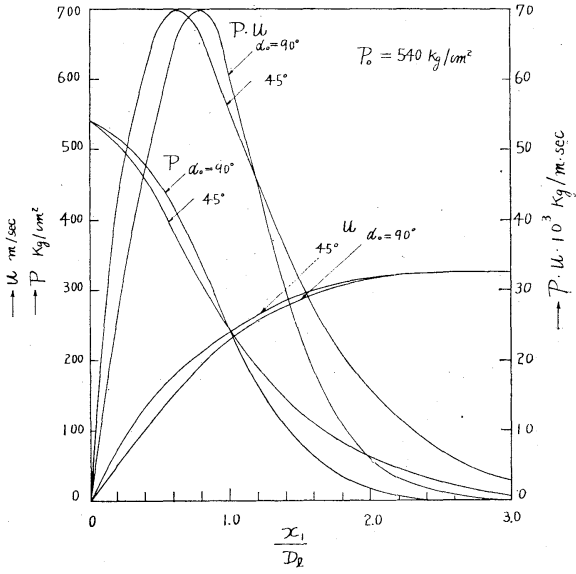

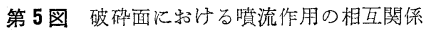

$$
\begin{aligned}
& -2 \sin \alpha_{0} \arccos \frac{r-\cos \alpha_{0}}{\sqrt{r^{2}+1-2 r \cos \alpha_{0}}}+\ln \frac{1+r}{1-r} \\
& \left.+2 \sin \alpha_{0}\left(\pi-\alpha_{0}\right)\right]
\end{aligned}
$$

（2）式に扣いて，噴流の吱点から下流については次の 条件で求められる。

$$
1>r>0
$$

また，噴流の岐点から上流についても同様にして，次 の条件で求めらる。

$$
0>r>-1
$$

これらの関係を第 3 図に示し，実線は下流について，

破線は上流について表わしている。

\section{$3 \cdot 3$ 破砕面における噴流厚さ}

噴流の岐点から下流の噴流厚さ $a_{1}$ および上流の $a_{2}$ に ついては, 次式により求められる。

$$
\begin{aligned}
a_{1} & =\frac{D_{l} \cdot\left(1+\cos \alpha_{0}\right)}{2} . \\
a_{2} & =\frac{D_{l} \cdot\left(1-\cos \alpha_{0}\right)}{2} .
\end{aligned}
$$

これらの関倸を第 4 図に表わした。

\section{$3 \cdot 4$ 破砕面における圧力および流速分布}

破砕面に打ける噴流の作用点は，速度比 $r$ を党れば (2)式で求められ，かつその点の圧力は次式でえられる。

$$
P=\frac{\gamma}{2 g} \cdot V^{2} \cdot\left(1-r^{2}\right)
$$

なお，筆者らの行なつた実験結果について，破砕面の 圧力お上び流速分布を, 吹き付け角度 $\alpha_{0}=90^{\circ}$ 打よび $45^{\circ}$ について求めた。その結果を第 5 図に表わした。

\section{5 破砕面における圧力と流速との相関関係}

破砕面に打情王力と流速が求められたので，これら の圧力と流速との積をとつて示せば，第 5 図のように， 積の最大となる噴流の作用点があることがわかる。した がつて; 筆者らの行なつた実験結果, すなわち衝撃領域 周辺部の環状のくぼみが存在する点が，いま理論的に求 めた珅力と流速の積の最大となる作用点とほぼー致して いることがみられた。

\section{4. む す び}

本報告に扔いては，水力破砕機棈の解明にあたつて， 流体力学的に実験結果を考察する一方法を述べたるので める。今後は破砕現象の高速度写真により解析を行なつ て, 流体力学的に検討する予定である。

\section{記号}

$D_{0}, D_{l}=$ ノズルロ径および距離 $l$ に打ける噴流径 $[\mathrm{m}]$

$e_{1} \quad$ =噴流中心軸から岐点の座標 [m]

$\mathrm{M}$ =岐点

$\mathrm{O}_{1}=$ 噴流中心軸と破砕面との交点

$x$ =岐点からの噴流作用点の座標 $[\mathrm{m}]$

$\alpha_{0}=$ =噴流の吹き付け角度 [ $\left.\mathrm{rad}\right]$

$r=$ 速度比 $\frac{u}{V}$

$V, u=$ 噴流の平均速度扣よび破砕面での速度 $[\mathrm{m} / \mathrm{sec}]$

$x_{0}, y_{0}=$ 破砕面で噴流の最外側の流線上の点の座標 [m]

$a_{1}, a_{2}$ 二破砕面に拈ける下流扣よび上流の噴流厚さ [m]

$P$ =破砕面に拈ける圧力 $\left[\mathrm{kg} / \mathrm{cm}^{2}\right]$

$\gamma=$ 水の比重量 $\left[\mathrm{kg} / \mathrm{m}^{3}\right]$

$g=$ 重力加速度 $\left[\mathrm{m} / \mathrm{sec}^{2}\right]$

\section{参考 文 献}

1）ムーチニク・イグナトフ編：水力採炭と水力輸送, 上巻 123 , 東 京大学出版会

2). 外尾善次郎 : 水力シェットの主要パラメータと水力打撃時の炭尿 内応力分布淿ついて, 日本鉱業会誌, Vol. 81 No. 930 (1965). pp. 907 912.

3) F. P. Bowden \& D. Tabor: The Friction \& Lubrication of Solids, Part II Oxford (1964) pp. 479 501.

4) А. А. Семерчан, Л. Ф. Верещаган, Ф. М. Филлер, Н. Н. Кузин : К Вопросу О Теории Разрушающего Действия Кавитации, ИНЖ-ФИЗЖУР, Том. 3 №. 3. (1960) st. 87 90.

5) W. Schach : Umlekung eines freien Flüssig Keittsstrahles. an einer ebenen Platte, Ingenieur-Archiv, $\mathrm{V} \mathrm{Bd}, 4 \mathrm{Heft}$, S. $245 \sim 265$ (1934). 